communities for generations, similar studies should be undertaken, distributed as widely as possible over the country, before improved communications break down this isolation. 'The present observations appear to bear out the author's contention that such a series of records is bound to throw light on the occurrence of rare recessive characters, which are much less likely to occur when random mating is the rule rather than the exception. The village here under study consisted of about fifteen hundred inhabitants. Observations of numerous morbid data extended over a period of years, and led to the conclusion that heredity plays an even more important part in many varied conditions than is generally recognized. Of the many conditions studied, eight were chosen for discussionhereditary cerebellar ataxia, progressive muscular dystrophy, the lymphatic diathesis, otitis media, hernia, cancer of the bowel, rodent ulcer and hydramnios. Among the more significant points which emerge, it is noted that in progressive muscular dystrophy, the condition is definitely sex-linked. It is transmitted by apparently healthy females in three generations. In three cases it was associated with failure to bleed, a peculiarity not previously recorded in this connexion. The incidence of hernia is curiously restricted. Out of twenty cases, fifteen occurred in two families; and heredity evidently played a part even more important than strain. The possibility of the occurrence of a zygotic lethal factor in the malea possibility suggested with some doubt by Ruggles Gates-receives support from the study of hydramnios, where there may be a relationship of the cases on the paternal, and not the maternal side.

\section{Natural and Synthetic Fibres: Sisal and Flax}

INTERESTING information on the development of natural and synthetic fibre industries is published in the Journal of the Royal Society of Arts (87, No. 4494). Discussing sisal and flax production in East Africa, Dr. W. H. Gibson maintains that the sisal industry is now well established in Kenya, binder twine and string being at present the chief uses for the fibre. Sisal is also finding a ready market for matting and upholstery filling, and tests regarding rope manufacture are giving satisfactory results. The flax industry in Kenya, on the other hand, has so far been less successful, due largely to the difficulties encountered in the process of retting, that is, the preliminary steeping process during which the fibres are loosened from the woody stem. Experiments recently carried out in the United Kingdom, however, have shown that it is possible to eliminate this process and extract the fibre from the natural flax, and with this discovery the way for the development of the industry in Kenya and other suitable parts of the Empire seems most promising.

THE modern counterpart of these vegetable fibres, namely, the synthetic textiles, are the subject of a paper by Dr. E. F. Armstrong. Artificial silk produced from wood pulp and its more recent development, staple fibre, are well-known supplements to, and competitors with, natural silk, wool and cotton. A new textile called' Nylon' has, however, recently been produced by the du Pont Laboratories in the United States. This thread is of an entirely different origin to rayon, as it is a plastic substance derived ultimately from coal tar, with dyeing properties akin to natural silk or wool, and it appears to have a most promising future. Two other types of fibre may be mentioned. The first is 'Lanital', an Italian product made from casein and used as a wool substitute, but as it lacks wet strength, attempts are being made to produce a better product from the protein of the soya bean. The second is spun glass which, though unsuitable for clothing, is used for electrical insulation, gas and liquid filtration and decorative purposes. In spite of the popularity of synthetic textiles, it is noteworthy that in 1937 the world production of these fibres was only in the ratio of 1.8 to 28 of natural spinning materials.

\section{Forestry in Finland in 1937}

THE annual report of forestry activities in Finland (XVII Metsätilasto Forststatistik-Kertomus Metsahallinnon Toiminnasta 5, 1937. Berättelse över Forstförvaltningens Verksamhet, Ar 1937), published in Helsinki last year, sums up the work of this progressive Forest Department. The great advance made by Finland since the Great War and the position she has taken in European forestry circles may to some extent be attributed to the fact that the Forest Department had a large forest capital at its back already under exploitation. Consequently a variety of problems were presented to the trained forester, from forestry education through sylvicultural management and protection down to the study of utilization, the improvements possible in extraction, statistics and prices, and so forth. The forestry reforms of 1921-23 prescribed the division of the country into four districts containing ten forest inspections and ninety cantonments (subdivisions of an inspection). Each district was administered by a local forestry bureau, under whom were the inspections, each in charge of an inspector. An important outcome of a decree of July 1934 is the gradual replacement of the untrained forest guards by chefs de travail or overseers, all of whom will have received training at one of the forestry schools, of which there are six. Considerable progress has been made with working plans and maps required in connexion with their preparation-revision of these plans is undertaken every ten years. The report deals in detail with the commercial activities, since the forests play so important a part in Finnish economy, and the British market is a very valuable one. An interesting point in the report is the policy undertaken by Government of settling a proportion of the population within the large forest areas owned by the State.

\section{The Phenological Survey}

THE new phenological forms distributed by the Royal Meteorological Society to its six-hundred-odd observers for 1939 have a further reconstruction of selected specimens of fauna and flora on a much more scientific basis. A noticeable feature is a considerable increase in the number of Lepidoptera selected for special observation, there being fifty selected 